\title{
Building-integrated Solar Collector (BISC)
}

\author{
Bin-Juine Huang ${ }^{1, *}$, Yu-Hsing Lin ${ }^{1}$, Wei-Zhe Ton ${ }^{1}$, Tung-Fu Hou ${ }^{1}$, Yi-Hung Chuang ${ }^{1}$ \\ ${ }^{1}$ New Energy Center, Department of Mechanical Engineering National Taiwan University, Taipei, Taiwan \\ * Corresponding author. Tel: +88622363-6576, Fax: +8862 2363-6576,E-mail: bjhuang@seed.net.tw
}

\begin{abstract}
The present study intends to develop building-integrated solar collector (BISC). The storage tank inside is designed in multi-function. BISC combines the solar collector and the water storage tank together with one face acting as the solar absorber. A double-glazing design is adopted to reduce the heat loss. A PC-based automatic operating system is designed and built to monitor the long-term performance of the BISC system with 8 collector units. Hot water discharge is controlled from 18:00 until 22:00 to simulate the hot water load of a family. The discharge rate is at $60 \mathrm{~L} / \mathrm{hr}$. A $30 \mathrm{~L}$ backup electric water heater was connected to the BISC system. The long-term test results in winter season show that about $50 \%$ energy saving was achieved in clear days. The monitored results have also shown that the daily-total solar irradiation on a $75^{\circ}$ tilted surface (the BISC installed angle) is higher than the horizontal surface, about $40-50 \%$ higher at $\mathrm{Ht}>10 \mathrm{MJ} / \mathrm{m}^{\wedge} 2$ day. This assures that BISC will produce more hot water in winter. This proves that the use of BISC as parapet or sun-shading canopy of a building (installation angle $>75^{\circ}$ ) is technically feasible. The characteristic efficiency of the installed BISC with different colors is $0.34-0.39$.
\end{abstract}

Keywords: Solar thermal, Building-integrated collector, Solar collector.

\section{Nomenclature}

$\eta$ the daily-total thermal efficiency of BISC..

$\eta^{*} \quad$ the characteristic daily thermal efficiency of BISC.

$\alpha_{o} \quad$ solar collecting efficiency $\left(\right.$ when $\left.T_{i}=T_{a}\right) \ldots$

$U_{s}$ the heat loss coefficient .......... MJ $/ \mathrm{m}^{20} \mathrm{C} \cdot$ day

$T_{i} \quad$ initial temperature when collect heat $\ldots . . .{ }^{\circ} \mathrm{C}$

$T_{a}$ average ambient temperature ................ ${ }^{\circ} \mathrm{C}$

$H_{T}$ the daily-total solar irradiation $M J / \mathrm{m}^{2}$.Day $\eta_{d c}$ the heat removal efficiency.

$\tau_{f}$ spent time when heat removal......... second

$m_{e}$ the heat removal flow rate.................. $\mathrm{kg} \cdot \mathrm{s}^{-1}$

$C_{p}$ specific heat of water................... MJ $/ \mathrm{kg} \cdot{ }^{\circ} \mathrm{C}$

$T_{e} \quad$ water outlet temperature .......................... ${ }^{\circ} \mathrm{C}$

$T_{w i}$ water inlet temperature .......................... ${ }^{\circ} \mathrm{C}$

$M_{t}$ total mass of water storage .................... $\mathrm{kg}$

$T_{\text {intial }} .$. initial temperature of water storage tank

\section{Introduction}

The solar building involves advanced solar collector technology for heating and hot water supply. Our research intends to develop a building-integrated solar collector (BISC) as parapet or sun-shading canopy of a building, Figure 1.1. B ISC has a dual function of solar utilization and building constructing material, which can greatly reduce the cost.

As part of the building constructing material, the design of BISC needs to consider the thermal performance, the mechanical strength, installation method on building, and outlook. We focus on the research of the thermal performance including heat utilization efficiency of hot water and the heat insulation of the front side.
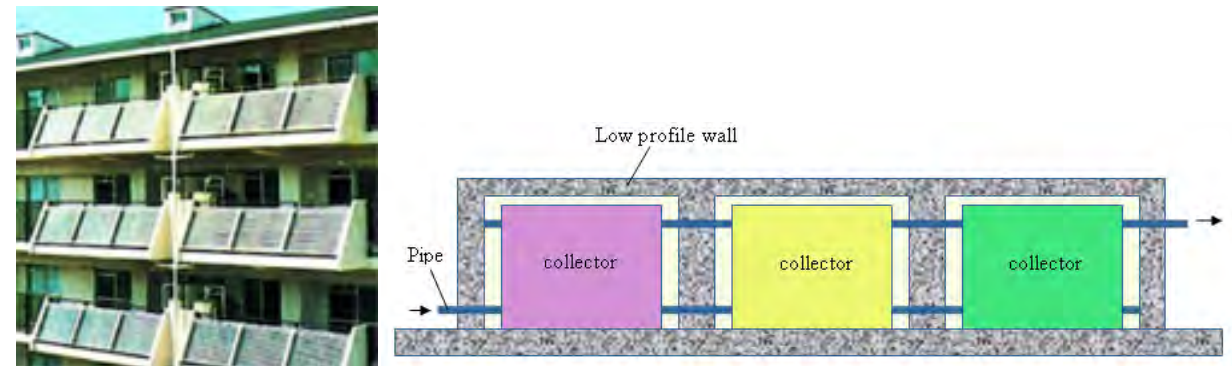

Fig. 1.1 BISC for parapet or sun canopy of a building 
We have developed the first generation product of BISC. The special design features of BISC include:

1) Color glass cover: BISC uses the color glass cover in order to be compatible with building. It will match the architecture appearance by choosing the glass color.

2)Modular design: The solar water heater is designed as a module and easy to install. It only needs to fix on the wall or the ground and connect the water supply lines.

3)Multi-function water storage tank: The BISC combines the solar collector and the water storage tank together. It combines the solar collector and the water storage tank together. One surface of the water storage tank is the solar absorber which absorbs solar energy and directly conducts to the water inside the storage tank.

4)Double air-layer insulation: The BISC has a double-layer insulation, with two air gaps in front of the collector. This can reduce the heat loss.

\section{Methodology}

\section{Design of BISC}

The design specification of the BISC unit is as follows:

- outside dimension: $100 \mathrm{~cm}$ x $70 \mathrm{~cm} \times 20 \mathrm{~cm}$

- solar absorber dimension: $90 \mathrm{~cm}$ x $60 \mathrm{~cm}$

- storage tank: $90 \mathrm{~cm} \times 60 \mathrm{~cm} \times 7.5 \mathrm{~cm}$

- water storage: 40 liter

- glazing: 2 layers, $4 \mathrm{~mm}$ color glass $+6 \mathrm{~mm}$ PC

- glass color: clear, ocean blue, French green

- front double air layer insulation: $3 \mathrm{~cm} / 3 \mathrm{~cm}$

- heat exchanger: PC $6 \mathrm{~mm}, 60 \mathrm{~cm} \times 90 \mathrm{~cm}, 3$ rows, $3.2 \mathrm{~m}^{2}$

There were 8 units of BISC were installed in the building for demonstration and field test. Figure 2.1 is the $3 \mathrm{D}$ drawings of BISC. Figure 2.2 is the real BISC. Figure 2.3 is the building installation of BISC.

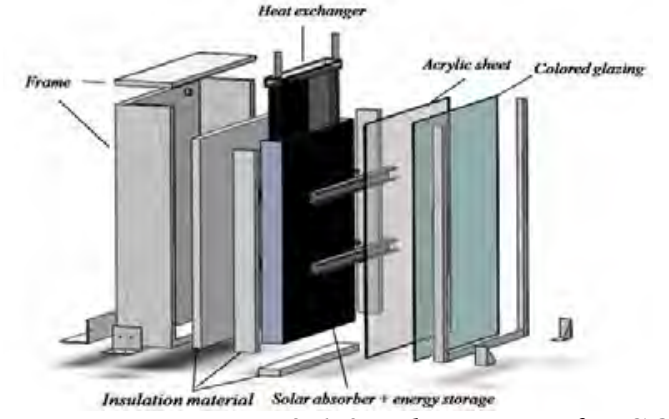

Fig. 2.1 3D drawings of BISC.

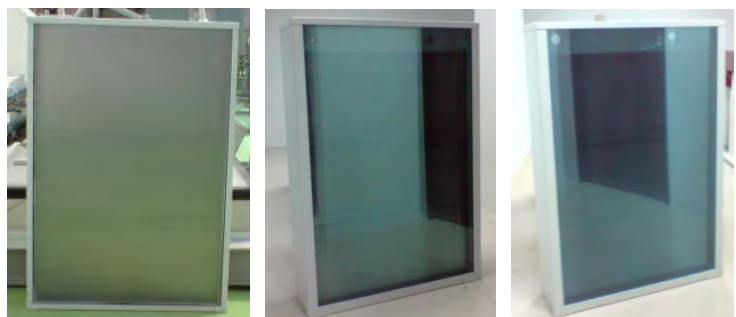

Fig.2.2 Color glass: clear, green, blue.

Equations (1) and (2) are used to determine the daily-total thermal efficiency of BISC (equation 1) and heat removal efficiency (equation 2):

$$
\begin{aligned}
& \eta=\alpha_{o}-U_{s} \frac{T_{i}-T_{a}}{H_{T}} \\
& \eta_{d c}=\frac{\int_{0}^{\tau_{f}} m_{e} C_{p}\left[T_{e}(t)-T_{W i}\right] d t}{M_{t} C_{p}\left(T_{\text {inital }}-T_{W i}\right)}
\end{aligned}
$$

The heat removal efficiency $\eta_{\mathrm{dc}}$ is defined as the ratio of the withdraw of total amount of useful heat compared to the total heat stored at sunset. Testing equipment for the measurement of daily-total thermal efficiency of BISC was designed and built in the research. 
The equipment setups are shown in Figure 2.4. This testing equipment is automatic from early in the morning to sunset.

Design of a BISC system for a family

Figure 2.5 is the BISC system design to supply hot water for a family.

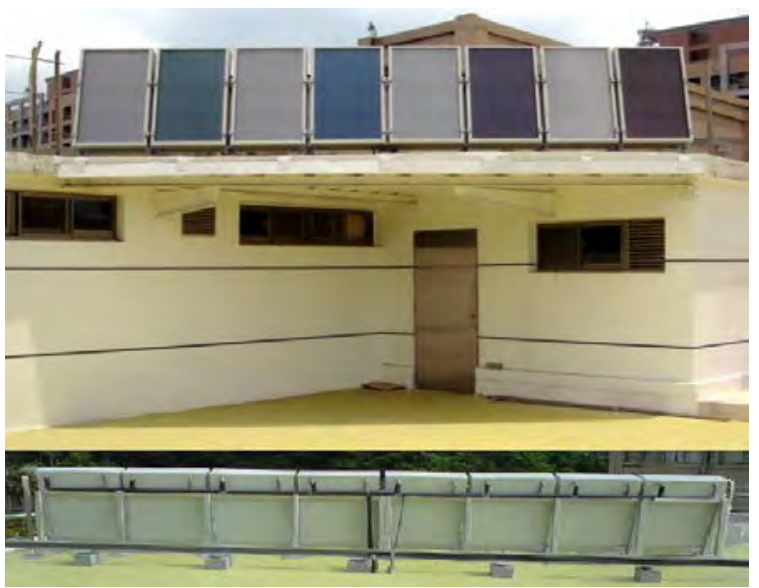

Fig. 2.3 BISC installation

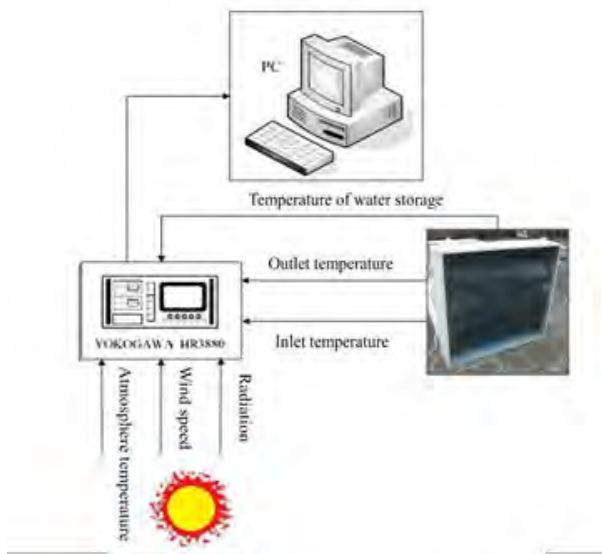

Fig. 2.4 BISC test equipments

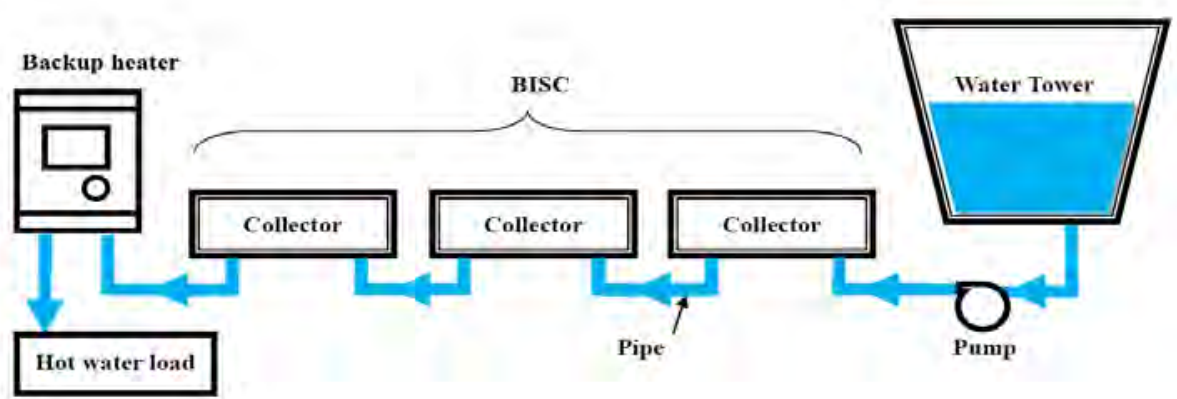

Fig. 2.5 BISC system.

Design of BISC system automatic monitoring system

A PC-based automatic operating and control system is designed and built to monitor the longterm performance of the BISC system built in the research. The operating system (Figure 2.6) monitors the instantaneous performance of the BISC system all day. Hot water discharge is controlled from 18:00 to simulate the hot water load of a family. The discharge rate is $30 \mathrm{~L}$ at every 15 minutes with 15 minutes stop after each discharge until 22:00. That is, the discharge rate is at $60 \mathrm{~L} / \mathrm{hr}$. A $30 \mathrm{~L}$ backup electric water heater was connected to the BISC system. The temperature setting of the backup heater is $55^{\circ} \mathrm{C}$.

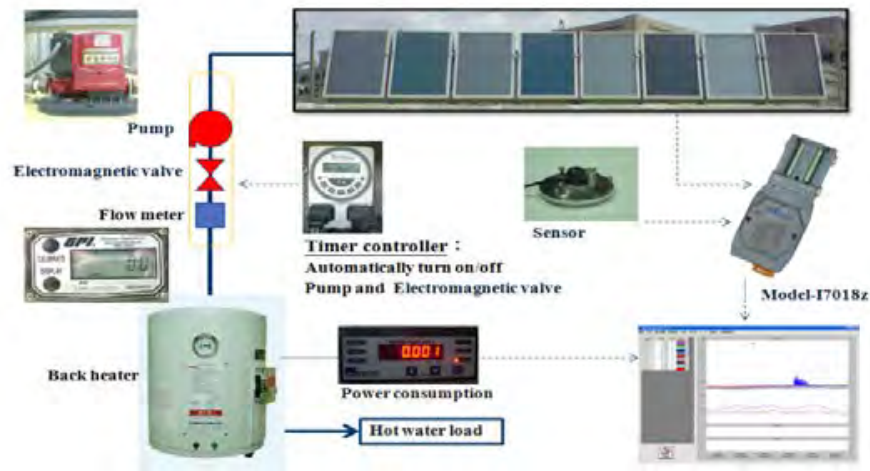

Fig. 2.6 Automatic monitor and control system 
Figure 2.7 shows the water outlet temperature from BISC system. Figure 2.8 shows the electric consumption of the backup water heater. Figure 2.9 shows the daily performance pattern.

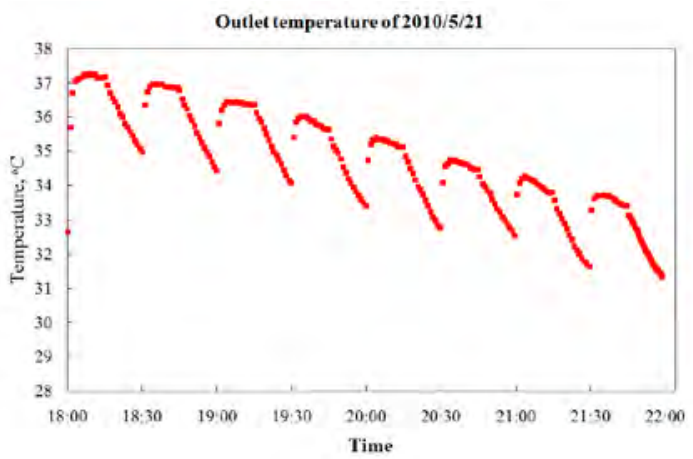

Fig. 2.7 BISC system outlet temperature

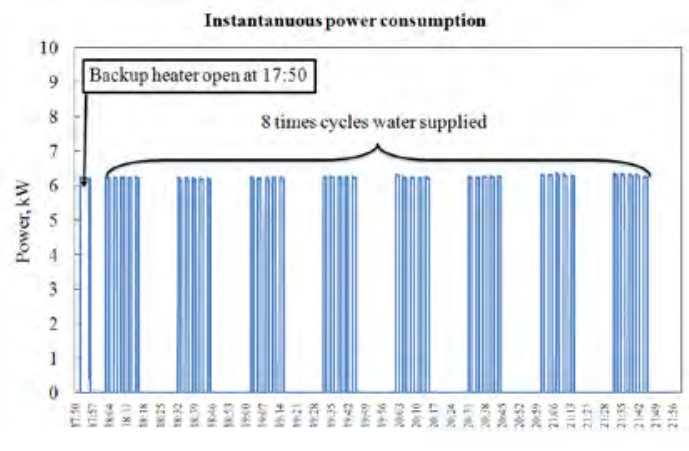

Fig. 2.8 Backup heater power consumption

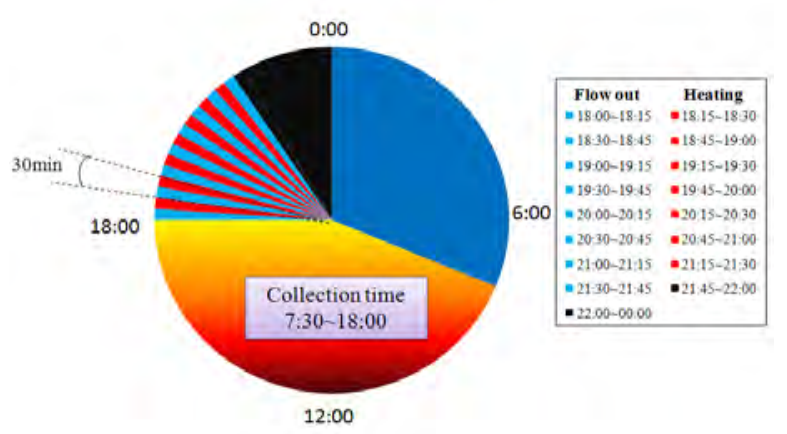

Fig. 2.9 Daily operation of BISC system.

\section{Results}

\subsection{Measurement of daily thermal performance of BISC installed in building}

Daily-total thermal efficiency test at $75^{\circ}$ tilt

The data collected from the BISC system installed in building can be used to analyze the thermal performance of BICS at the installed tilt angle $\left(75^{\circ}\right)$, using the testing standard CNS B7277 developed by Huang [1-5]. The daily-total thermal efficiency tests were performed for BISC installed at $75^{\circ}$ tilted angle with different color glazing, all facing south.

The daily-total efficiency is calculated using the measurement of daily-total energy stored in the storage tank and the total solar irradiation. Figure 3.1-1 Figure 3.1-5 and Table 3.1-1 present the daily-total thermal efficiency of BISC. The test results show that the characteristic efficiency of BISC with different colors which are installed in building with $75^{\circ}$ tilt angle is 0.34-0.39 which is lower than the conventional solar water heater $(0.50)$ with clear glass and tilted at lower angle $\left(25^{\circ}\right)$. 


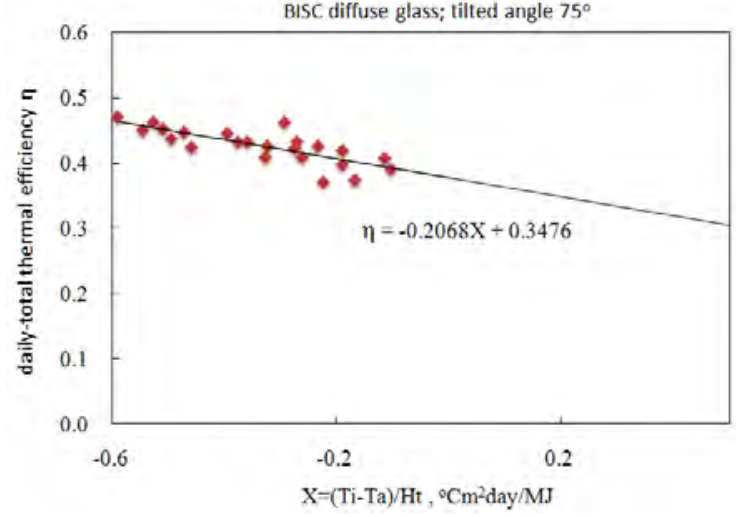

Fig. 3.1-1 Daily-total efficiency of BISC (diffuse glass).

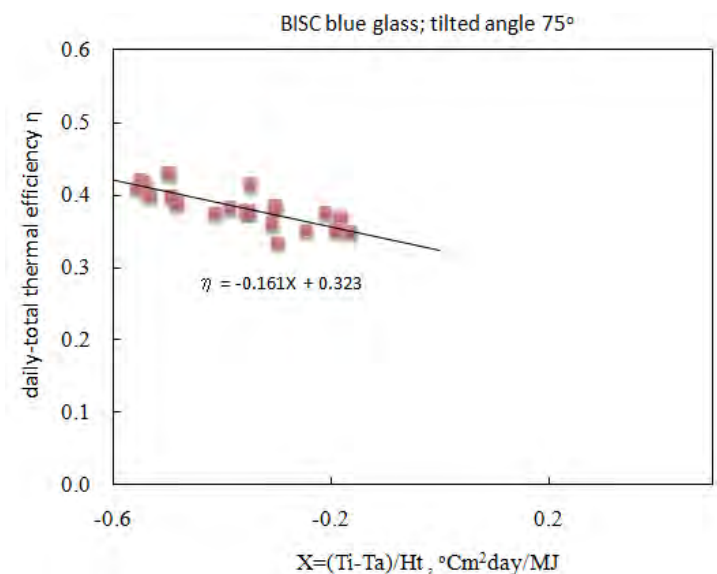

Fig. 3.1-3 Daily-total efficiency of BISC (blue glass).

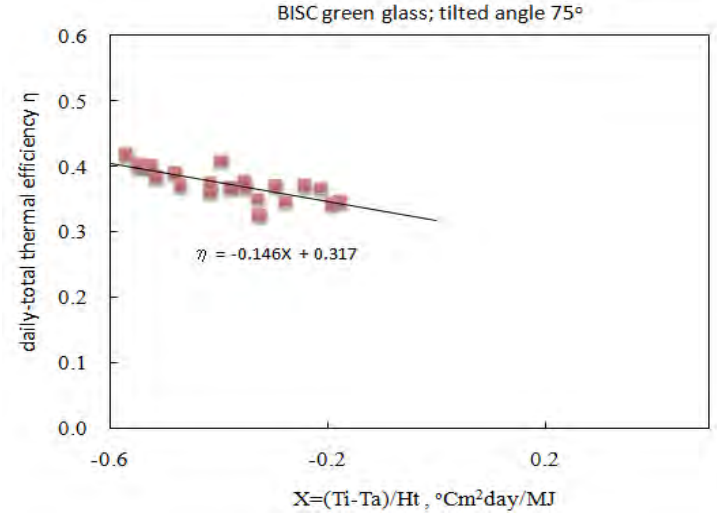

Fig. 3.1-2 Daily-total efficiency of BISC (green glass).

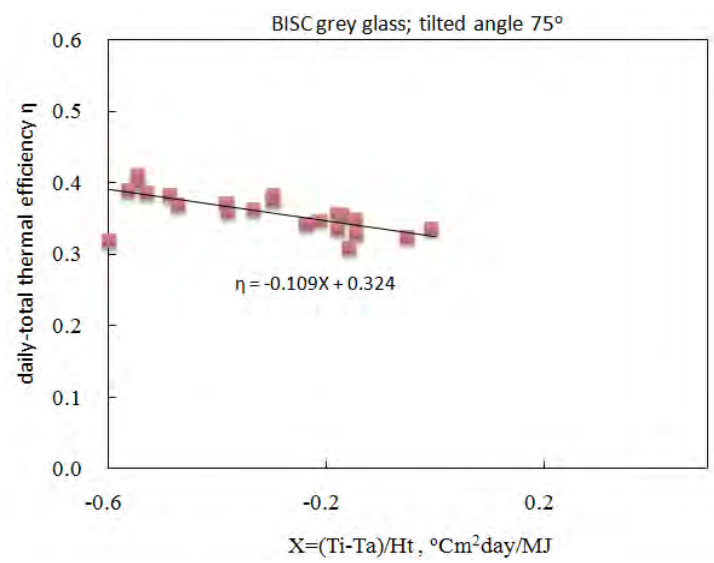

Fig. 3.1-4 Daily-total efficiency of BISC (grey glass).

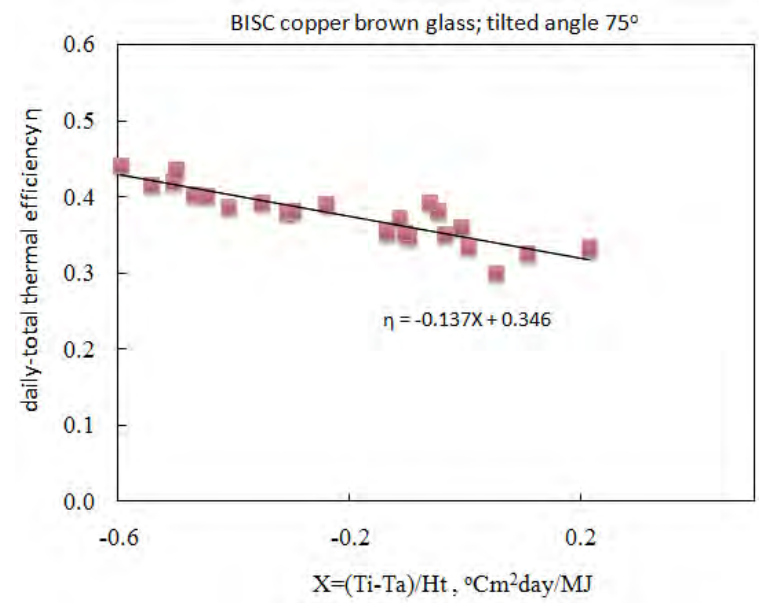

Fig. 3.1-5 Daily-total efficiency of BISC (brown glass).

Table 3.1-1 Test results of daily-total efficiency of BISC.

\begin{tabular}{lccc} 
BISC facing South & $U_{S}$ & $\alpha_{o}$ & $\eta^{*}$ \\
\hline Diffuse glass, tilted $75^{\circ}$ & 0.207 & 0.348 & 0.39 \\
Green glass, tilted $75^{\circ}$ & 0.147 & 0.318 & 0.35 \\
Blue glass, tilted $75^{\circ}$ & 0.161 & 0.323 & 0.35 \\
Grey glass, tilted $75^{\circ}$ & 0.109 & 0.325 & 0.34 \\
per-brown glass, tilted $75^{\circ}$ & 0.137 & 0.346 & 0.36
\end{tabular}




\subsection{Long-term thermal performance test of BISC}

The BISC system installed in building is tested by simulating the daily operation for a family. To estimate the energy saving of the backup electric heater, a baseline test was carried out to measure the daily energy consumption of the electric heater without using BISC. At daily solar irradiation $0.62 \mathrm{MJ} / \mathrm{m}^{\wedge} 2$ which is assumed as no s olar radiation (rainy, the daily electricity consumption is $11.1 \mathrm{k} \mathrm{Wh}$. At daily solar irradiation $21.7 \mathrm{MJ} / \mathrm{m}^{\wedge} 2$ (the best weather), the daily electricity consumption is $4.0 \mathrm{kWh}$.

The first long-term performance monitoring is in winter season. Figure 3.2-1 shows the longterm monitoring results of BISC. It is shown that BISC can save $40 \%$ to $50 \%$ of electricity per day in winter. Figure 3.2-2 shows the variation of daily energy consumption and collected water temperature with solar irradiation in winter season. In spring season, the test results are shown in Figure 3.2-3 and Figure 3.2-4.

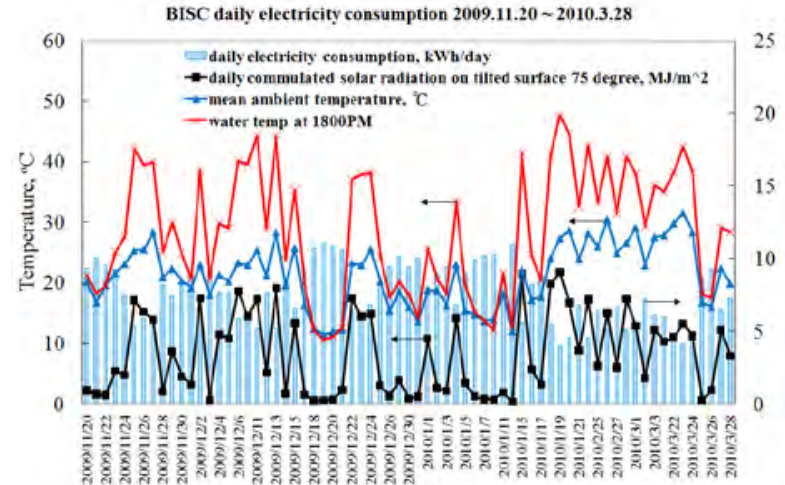

Fig. 3.2-1 Long-term monitoring results of BISC at Taipei 2009.11.20 2010.3.28.

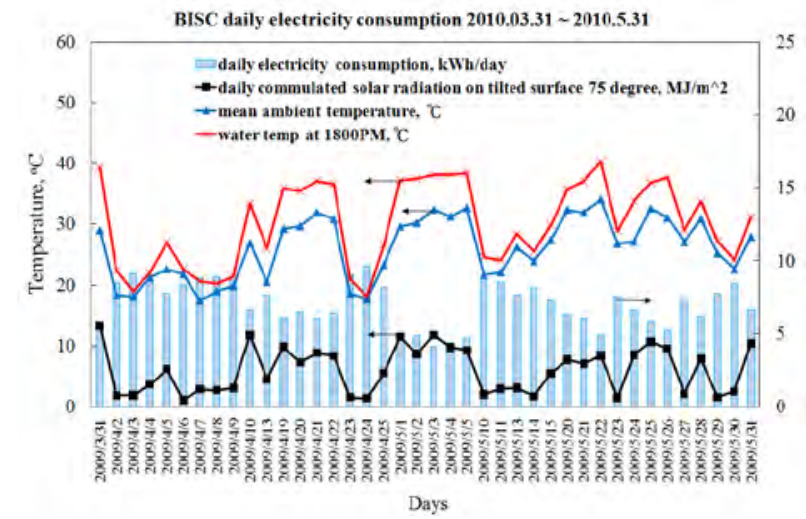

Fig. 3.2-3 Long-term monitoring results of BISC at Taipei 2010.3.31 2010.5.31

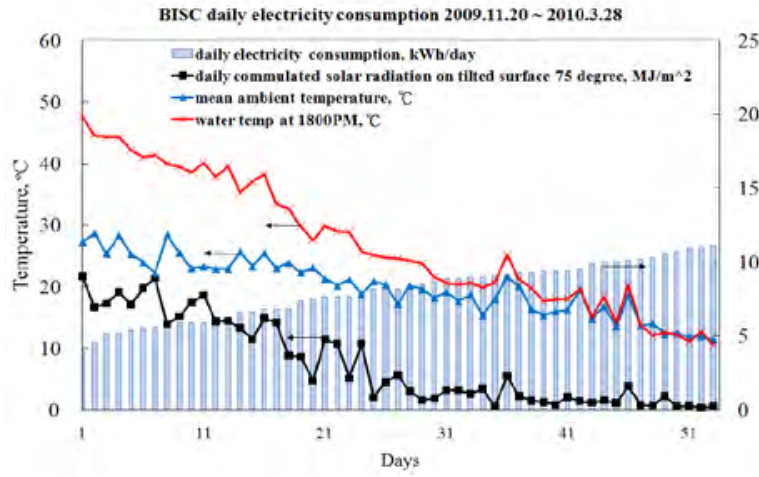

Fig. 3.2-2 Variation of daily energy consumption and collected water temperature with solar irradiation at Taipei 200911.20 2010.3.28

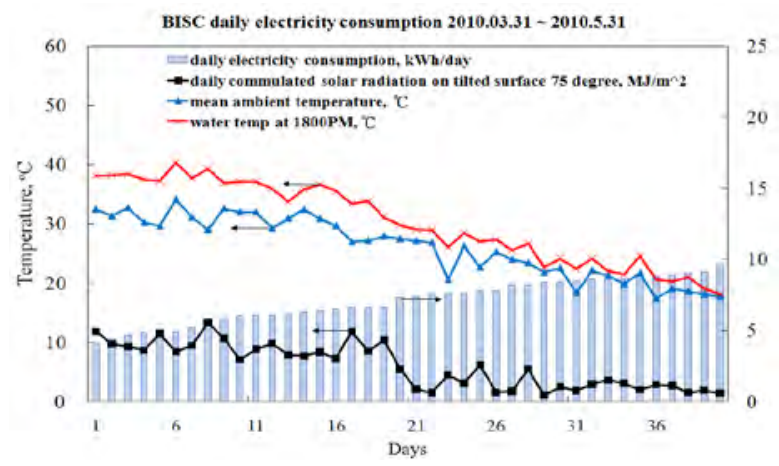

Fig. 3.2-4 Variation of daily energy consumption and collected water temperature with solar irradiation at Taipei 2010.3.31 2010.5.31

Figure 3.2-5 and Figure 3.2-6 shows the variation of daily-total solar irradiation on $75^{\circ}$ and horizontal surfaces. The monitored results have also shown that the daily-total solar irradiation on a $75^{\circ}$ tilted surface (the BISC installed angle in building) is higher than the horizontal surface, about $40-50 \%$ higher at $\mathrm{Ht}>10 \mathrm{MJ} / \mathrm{m}^{\wedge} 2$ day. This verifies that the use of BISC for parapet or sun-shading canopy of a building (installation angle $>75^{\circ}$ ) is feasible. In summer, it is expected that the solar irradiation on $75^{\circ}$ surface will be less than the horizontal one and the heat collection efficiency will be lower. However, the hot water load in summer decreases about $50 \%$ in summer. Therefore, the use of BISC as parapet or sun-shading canopy of a building is feasible. 


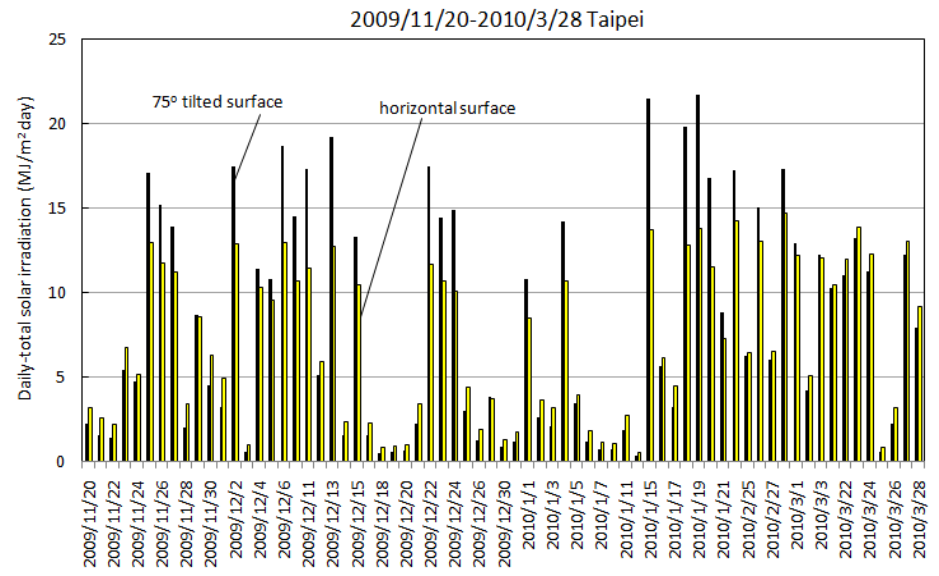

Fig. 3.2-5 Variation of daily-total solar irradiation $75^{\circ}$ and horizontal surfaces.

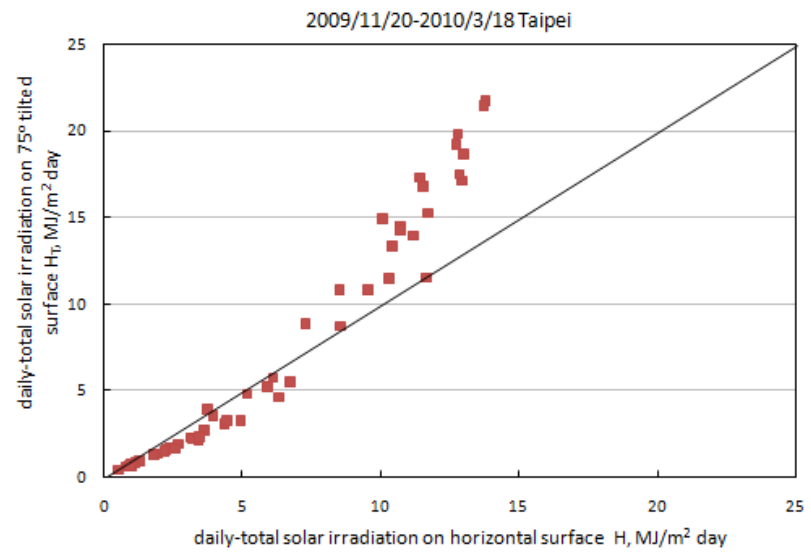

Fig. 3.2-6 Variation of daily-total solar irradiation on $75^{\circ}$ and horizontal surfaces.

\subsection{Heat removal efficiency test}

The heat removal efficiency test is carried out to determine how much energy can be extracted from the tank rated at the total water extraction identical with the storage volume. With the Figure 3.4-1 By the equation (2), we can see the numerator is the real instantaneous removal heat (similar a trapezoid area), and the denominator is the total storage heat (rectangle area), then the heat removal efficiency calculate about 0.72 .

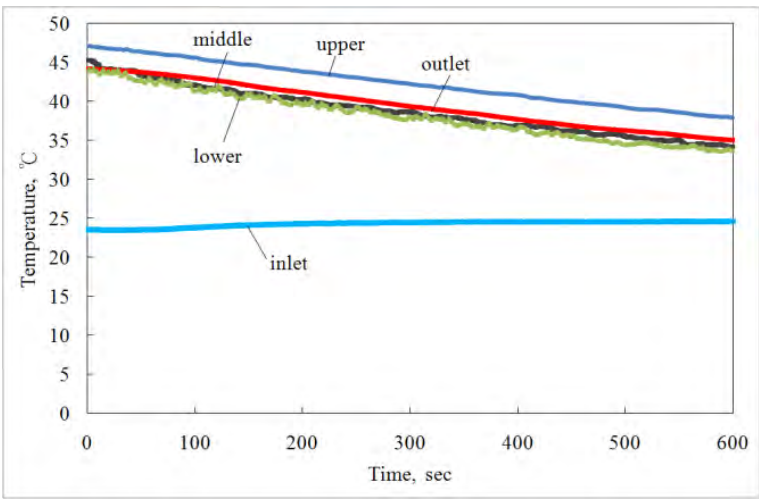

Fig. 3.4-1 Heat removal efficiency test.

\section{Discussion and Conclusions}

Our research intends to develop building-integrated solar collector (BISC). The BISC is designed to be part of construction material of a building. The storage tank inside is designed 
in multi-function. BISC combines the solar collector and the water storage tank together with one face acting as the solar absorber which absorbs solar energy and directly conducts to the water inside the storage tank. A double-glazing design is adopted to reduce the heat loss. The outer transparent cover (glass) is made of color glass for architecture requirement. 8 uni ts were installed on the roof of the lab at the Innovation and Incubation Center of NTU for field demonstration and test.

A PC-based automatic operating and control system is designed and built to monitor the longterm performance of the BISC system installed in the research. The system monitors the instantaneous performance of the BISC system all days. Hot water discharge is controlled from 18:00 to simulate the hot water load of a family. The discharge rate is $30 \mathrm{~L}$ at every 15 minutes with 15 minutes stop after each discharge until 22:00. That is, the discharge rate is at $60 \mathrm{~L} / \mathrm{hr}$. A $30 \mathrm{~L}$ backup electric water heater was connected to the BISC system. The temperature setting of the backup heater is at $55{ }^{\circ} \mathrm{C}$ which is fixed. The long-term test results in winter season show that about $50 \%$ energy saving was achieved in clear days. The monitored results have also shown that the daily-total solar irradiation on a $75^{\circ}$ tilted surface (the BISC installed angle in building) is higher than the horizontal surface, about $40-50 \%$ higher at $\mathrm{Ht}>10 \mathrm{MJ} / \mathrm{m}^{\wedge} 2$ day. This assures that BISC will produce more hot water in winter. This proves that the use of BISC as parapet or sun-shading canopy of a building (installation angle $>75^{\circ}$ ) is technically feasible. The test results show that the characteristic efficiency of BISC with different colors which are installed in building with $75^{\circ}$ tilt angle is $0.34-0.39$, lower than the conventional solar water heater $(0.50)$.

The monitoring of long-term performance will be continued to find out the defects and efficiency of the system. Since BISC is part of the building, it needs a BISC with high quality in art design, high thermal performance, good manufacturing technique, and long service life (reliability). The reliability issue will be the focus of forthcoming research.

\section{Acknowledgment}

This publication is based on work supported by Award No. KUK-C1-014-12, made by King Abdullah University of Science and Technology (KAUST), Saudi Arabia

\section{References}

[1] B. J. Huang and S. C. Du, "A performance test method of solar thermosyphon system", ASME Journal of Solar Energy Engineering, Vol.113, pp.172-179.(1991)

[2] Test Standard CNS B7277, Method of Test for Solar Water Heater System, 1988. Taiwan.

[3] B. J. Huang, "Performance rating method of thermosyphon solar water heaters". Solar Energy, Vol.50, No5, pp.435-440.(1993).

[4] J. M. Chang, "A Proposed Modified Efficiency for Thermosyphon Solar Heating Systems", Solar Energy, Vol. 76, No. 6, pp.693-701. (2004)

[5] J. M. Chang,"A Criterion Study of Solar Irradiation Patterns for the Peroformance Testing of Thermosyphon Solar Water Heaters," Solar Energy, Vol. 73, No. 4, pp.287292.(2002)

[6] B. J. Huang,'Development of Long-Term Performance Correlation for Solar Thermosyphon Water Heater". ASME Journal of Solar Energy Engineering, Vol.111, pp.124-131. (May 1989) 